\title{
MICROPROPAGATION OF SCUTELLARIA BAICALENSIS GEORGI
}

\author{
Anna Stojakowska, JanuSz MaLarZ, StanisŁaW KOHLMÜnZER \\ Department of Phytochemistry, Institute of Pharmacology \\ Polish Academy of Sciences \\ Smętna 12, 31-343 Kraków, Poland
}

(Received: December 4, 1998. Accepted: April 16, 1999.)

\begin{abstract}
Plant propagation via nodal explants of Scutellaria baicalensis Georgi (Lamiaceae) was studied. Murashige and Skoog (MS) medium supplemented either with NAA and kinetin or NAA and BA in different concentrations was used for this purpose. The most favourable for axillary branching was MS medium supplemented with $0.5 \mu \mathrm{M}$ NAA and $2.5 \mu \mathrm{M}$ kinetin. The number of regenerated shoots per explant reached $3.8 \pm 1.3$. To increase the multiplication rate a two stage procedure of propagation was also elaborated. First, an induction of organogenic calli was achieved using thidiazuron (TDZ) as a sole growth regulator in the nutrient medium (concentration range: 0.1-0.5 $\mu \mathrm{M}$ ). Next, regeneration of shoots on the medium containing $2.2 \mu \mathrm{M}$ BA was performed. Over 20 shoots per explant could be obtained following the described procedure. The regenerated shoots rooted easily on a modified MS medium (1/2 macronutrients) and were successfully adapted to growth in pots.
\end{abstract}

KEY WORDS: Scutellaria baicalensis, axillary shoots, caulogenic callus, micropropagation.

\section{INTRODUCTION}

Scutellaria baicalensis Georgi (Lamiaceae), a medicinal plant widely used in the Far East for the treatment of various inflammatory diseases, tumours and arteriosclerosis (YunChoi 1992) is a rich source of flavonoids of which baicalin (baicalein-7-O-glucuronide) and wogonin-7-O-glucuronide are the predominant constituents. Some of the flavonoids isolated from $S$. baicalensis proved to be pharmacologically active. They showed an affinity for the benzodiazepine binding site (Liao et al. 1998), bradykinin antagonistic effect (YunChoi et al. 1992), antiviral (Konoshima et al. 1992, Nagai et al. 1995), cytotoxic (Ryu et al. 1985), antioxidant (Gabrielska et al. 1997), antiarteriosclerotic and antithrombotic (Kimura et al. 1997a, b, c) activity.

Although some studies concerning cell suspension, callus and root culture of the plant have been published (Yamamoto 1991, Seo et al. 1993, Nishikawa and Ishimaru 1997), to our knowledge, an effective system for in vitro propagation of $S$. baicalensis has not been elaborated yet.

\section{MATERIAL AND METHODS}

\section{Plant material}

Aseptic plants of Scutellaria baicalensis Georgi were obtained from seeds delivered by the Central Garden of Medicinal Plants, Masarykian University (Brno, Czech Republic). The seeds were rinsed with ethanol, sterilized with a $15 \%$ solution of sodium hypochlorite and aseptically germinated on a hormone-free, solidified MS (Murashige and Skoog 1962) medium with $1 / 2$ strength macronutrients, at $25^{\circ} \mathrm{C}$ and continuous light (ca. $40 \mu \mathrm{mol} \mathrm{m} \mathrm{m}^{-2} \mathrm{~s}^{-1}$, cool white fluorescent tubes). After three weeks, the seedlings were transferred to solidified MS medium and cultivated under the same conditions. Shoots of the aseptic seedlings, ca. $8 \mathrm{~cm}$ long, with 5-7 nodes, were used as a source of primary nodal explants.

\section{Culture media}

The used nutrient media were solidified with $0.8 \%$ Difco Bacto-Agar, contained 3\% sucrose as a carbon source and their $\mathrm{pH}$ was adjusted to 5.8 , before autoclaving ( $20 \mathrm{~min}$ at $\left.121^{\circ} \mathrm{C}\right)$.

\section{Axillary shoot regeneration}

The nodal explants of S.baicalensis were inoculated on solidified MS media supplemented with various concentrations of growth regulators. Two series of media were prepared, containing either $\alpha$-naphthaleneacetic acid (NAA) and kinetin at a concentration range $0-10 \mu \mathrm{M}$ (Table 1) or a combination of NAA and 6-benzylaminopurine (BA) $(0-5 \mu \mathrm{M})$, (Table 2). An effect of 0.1-10.0 $\mu \mathrm{M}$ 1-phenyl-3-(1,2,3-thiadiazol-5-yl) urea (TDZ) on shoot formation from node explants of $S$. baicalensis was also studied (Table 3). All cultures were kept at $25^{\circ} \mathrm{C}$, under continuous light (ca. $40 \mu \mathrm{mol} \mathrm{m} \mathrm{m}^{-2} \mathrm{~s}^{-1}$, cool white fluorescent tubes).

For each treatment ten explants were used and every experiment was repeated. The multiplication rate, expressed as a number of shoots regenerated from one nodal explant within a culture period and frequency of response, i.e. percentage of 
TABLE 1. Shoot formation in nodal explants of S. baicalensis inoculated on MS medium supplemented with NAA and kinetin (after six weeks of culture).

\begin{tabular}{|c|c|c|c|c|c|}
\hline $\mathrm{NAA}[\mu \mathrm{M}]$ & Kinetin $[\mu \mathrm{M}]$ & $\%$ response & $\begin{array}{l}\text { Number of shoots per } \\
\text { explant }(>1 \mathrm{~cm})\end{array}$ & Roots & Callus * \\
\hline $\begin{array}{c}0 \\
0 \\
0 \\
0.5 \\
0.5 \\
0.5 \\
0.5 \\
2.5 \\
2.5 \\
2.5 \\
2.5 \\
2.5 \\
5.0 \\
5.0 \\
5.0 \\
5.0 \\
10.0 \\
10.0 \\
10.0 \\
10.0\end{array}$ & $\begin{array}{c}0 \\
2.5 \\
10.0 \\
0.5 \\
2.5 \\
5.0 \\
10.0 \\
0 \\
0.5 \\
2.5 \\
5.0 \\
10.0 \\
0.5 \\
2.5 \\
5.0 \\
10.0 \\
0.5 \\
2.5 \\
5.0 \\
10.0\end{array}$ & $\begin{array}{c}35 \\
70 \\
55 \\
55 \\
70 \\
70 \\
75 \\
80 \\
65 \\
90 \\
85 \\
90 \\
75 \\
75 \\
90 \\
100 \\
35 \\
100 \\
100 \\
100\end{array}$ & $\begin{array}{c}1.8 \pm 0.4 \\
3.6 \pm 1.6 \\
4.0 \pm 1.9 \\
3.8 \pm 1.8 \\
3.8 \pm 1.3 \\
2.6 \pm 0.5 \\
2.8 \pm 1.7 \\
1.9 \pm 0.3 \\
2.1 \pm 0.6 \\
1.3 \pm 0.7 \\
2.7 \pm 1.5 \\
- \\
2.6 \pm 0.8 \\
2.2 \pm 0.9 \\
2.0 \pm 0.9 \\
- \\
0.5 \pm 0.2 \\
1.9 \pm 0.8 \\
- \\
-\end{array}$ & $\begin{array}{l}- \\
- \\
- \\
- \\
- \\
- \\
- \\
- \\
+ \\
- \\
- \\
- \\
- \\
- \\
- \\
- \\
- \\
- \\
- \\
-\end{array}$ & $\begin{array}{l}- \\
- \\
+ \\
- \\
- \\
+ \\
+ \\
- \\
- \\
+ \\
+ \\
++ \\
+ \\
+ \\
+ \\
++ \\
- \\
+ \\
+ \\
++\end{array}$ \\
\hline
\end{tabular}

$*+<\operatorname{lg~FW}$

$++1-4 \mathrm{~g} \mathrm{FW}$

TABLE 2. Effect of BA and NAA concentration in the MS medium on shoot formation from node explants of S. baicalensis (after six weeks of culture).

\begin{tabular}{|c|c|c|c|c|c|}
\hline $\mathrm{NAA}[\mu \mathrm{M}]$ & $\mathrm{BA}[\mu \mathrm{M}]$ & $\%$ response & $\begin{array}{l}\text { Number of shoots per } \\
\text { explant }(>1 \mathrm{~cm})\end{array}$ & Roots & Callus * \\
\hline $\begin{array}{l}0 \\
0 \\
0 \\
0 \\
0.5 \\
0.5 \\
0.5 \\
0.5 \\
2.5 \\
2.5 \\
2.5 \\
2.5 \\
5.0 \\
5.0 \\
5.0 \\
5.0\end{array}$ & $\begin{array}{c}0 \\
0.5 \\
2.5 \\
5.0 \\
0 \\
0.5 \\
2.5 \\
5.0 \\
0 \\
0.5 \\
2.5 \\
5.0 \\
0 \\
0.5 \\
2.5 \\
5.0\end{array}$ & $\begin{array}{l}40 \\
85 \\
35 \\
30 \\
45 \\
35 \\
50 \\
35 \\
15 \\
45 \\
20 \\
15 \\
35 \\
20 \\
55 \\
35\end{array}$ & $\begin{aligned} & 1.9 \pm 0.3 \\
& 1.4 \pm 0.8 \\
&- \\
& 2.3 \pm 1.0 \\
& 1.7 \pm 0.5 \\
& 2.0 \pm 0.1 \pm 0.8 \\
& 5.0 \pm 0.8 \\
& 8.5 \pm 3.5 \\
&- \\
& 4.0 \pm 0.8 \\
& 3.0 \pm 1.2 \\
&- \\
& 2.5 \pm 0.5 \\
& 4.0 \pm 1.1 \\
& 6.8 \pm 2.9 \\
& 5.5 \pm 1.9\end{aligned}$ & $\begin{array}{l}- \\
- \\
- \\
- \\
- \\
+ \\
+ \\
- \\
- \\
- \\
- \\
- \\
+ \\
+ \\
- \\
-\end{array}$ & $\begin{array}{c}- \\
+ \\
+ \\
+ \\
++ \\
- \\
+ \\
++ \\
+ \\
+ \\
+ \\
+ \\
+ \\
+ \\
+ \\
++ \\
++\end{array}$ \\
\hline
\end{tabular}

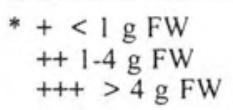

explants showing either callus or organ formation, were calculated for each treatment.

\section{Rooting of regenerated shoots}

After six weeks culture, the regenerated shoots were transferred to rooting medium, i.e. MS medium containing $1 / 2$ macronutrients, without growth regulators. Roots were successfully regenerated within two weeks. The obtained plants were either adapted to growth in pots or were used as a source of secondary explants for the next multiplication step.
Induction of shoot regeneration from caulogenic calli obtained on TDZ containing media

Nodal explants inoculated on MS media supplemented with various concentrations of TDZ produced calli. The calli induced on the media containing $0.1-0.5 \mu \mathrm{M}$ TDZ developed numerous shoot buds, however only those cultivated on the medium with $0.1 \mu \mathrm{M}$ TDZ were capable to regenerate some shoots (Table 3). To induce shoot development the caulogenic calli, after four weeks of growth on the medium containing $0.5 \mu \mathrm{M} \mathrm{TDZ}$, were transferred onto the MS medium sup- 
TABLE 3. Effect of TDZ on shoot formation from node explants of $S$. baicalensis (after four weeks of culture).

\begin{tabular}{c|c|c|c|c}
\hline TDZ $[\mu \mathrm{M}]$ & \% response & $\begin{array}{c}\text { Number of shoots } \\
\text { per explant }(>1 \mathrm{~cm})\end{array}$ & Roots & Callus * \\
\hline 0.1 & 100 & $2.1 \pm 1.0$ & - & + \\
0.5 & 100 & shoot buds & - & ++ \\
1.0 & 100 & - & - & ++ \\
5.0 & 100 & - & - & +++ \\
10.0 & 100 & - & - & +++ \\
\hline
\end{tabular}

$$
\begin{aligned}
& +<1 \mathrm{~g} \mathrm{FW} \\
& ++1-4 \mathrm{~g} \mathrm{FW} \\
& +++>4 \mathrm{~g} \mathrm{FW}
\end{aligned}
$$

plemented either with $2.2 \mu \mathrm{M}$ BA or with $0.01 \mu \mathrm{M}$ BA and $26 \mu \mathrm{M}$ of giberelic acid $\left(\mathrm{GA}_{3}\right)$. The shoots obtained within four weeks of growth on those media were rooted following the formerly described procedure.

\section{RESULTS AND DISCUSSION}

The most favourable for axillary shoot proliferation in nodal explants of S.baicalensis was the MS medium supplemented with $0.5 \mu \mathrm{M}$ NAA and $2.5 \mu \mathrm{M}$ kinetin (Fig. 1),

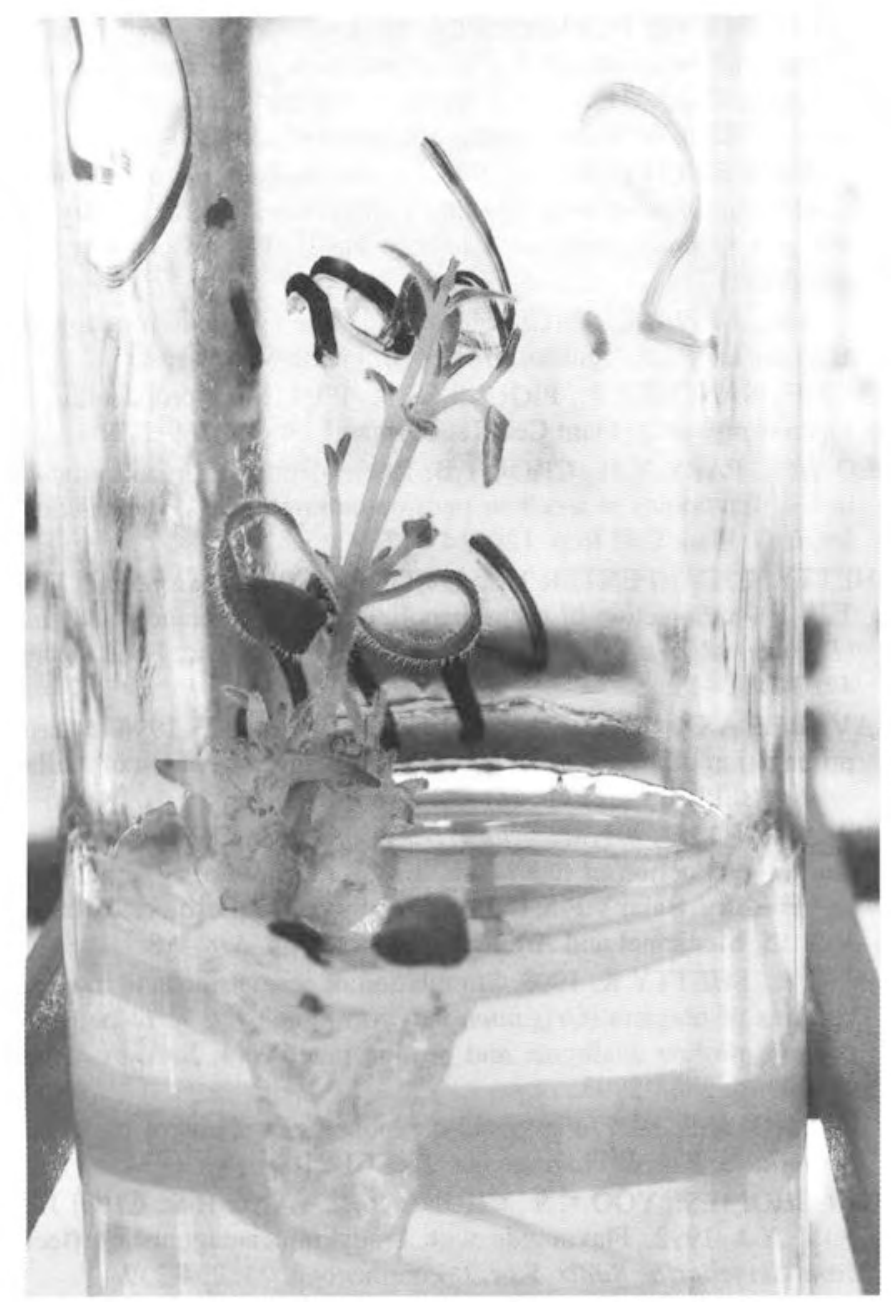

Fig. 1. Axillary shoot development from node explant of Scutellaria baicalensis Georgi on MS medium supplemented with $0.5 \mu \mathrm{M}$ NAA and $2.5 \mu \mathrm{M}$ kinetin. though the number of regenerated shoots per explant remained low $(3.8 \pm 1.3$ with $70 \%$ frequency). Other medium compositions, especially those containing NAA together with $\mathrm{BA}$ induced shoot proliferation with higher multiplication rate (up to $8.5 \pm 3.5$ ), but with lower frequency (35-55\%). Additionally, regeneration of shoots on those media was accompanied by callus outgrowth. The excised shoots, at least $1 \mathrm{~cm}$ long, were individually transferred to rooting medium. During the following two weeks of culture, elongation of shoots (both due to an increase in the length of internodes and the number of nodes) accompanied by root formation was taking place. An average of 4-5 nodes per one regenerated plant was obtained. Rooted plantlets were successfully adapted to the growth in pots (Fig. 2).

Several studies were devoted to micropropagation of $\mathrm{La}$ miaceae species through proliferation of axillary shoots. Culture media supplemented either with sole cytokinin (preferably BA) or with a combination of cytokinin with low concentration of auxin were used for this purpose. Tavares et al. (1996) obtained 24 axillary shoots per cotyledonary node explant of Melissa officinalis L. after 60 days culture on MS medium containing $8.9 \mu \mathrm{M}$ BA. Optimum shoot organogenesis through adventitious bud proliferation from apical meristem explants was achieved in Thymus vulgaris L. (Shetty et al. 1996) and Origanum vulgare L. (Yang and Shetty 1998) on MS medium supplemented with $4.4 \mu \mathrm{M}$ BA. Pattnaik and

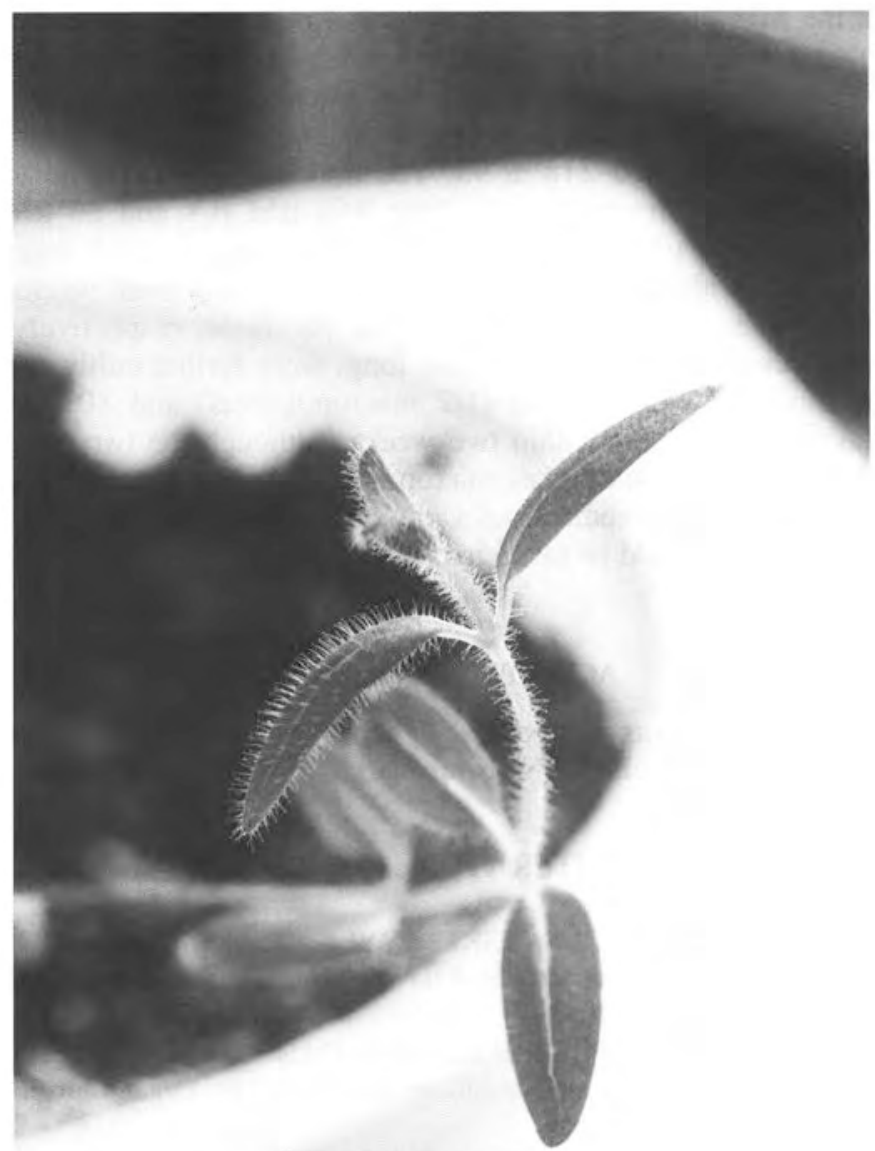

Fig. 2. In vitro regenerated plant of Scutellaria baicalensis Georgi adapted to growth in a pot. 
Chand (1996) elaborated a method of in vitro propagation of Ocimum americanum L. and Ocimum sanctum L. using axillary shoot buds. They found that the optimum BA concentration for proliferation of shoots was $1.1 \mu \mathrm{M}$ for $O$. americanum and $4.4 \mu \mathrm{M}$ for O.sanctum. According to their study an addition of $\mathrm{GA}_{3}$ to the medium improved both frequency of bud break and multiplication rate. Olszowska and Furmanowa (1992) used a combination of adenine sulfate (10 mg/l) and 3 indolebutyric acid (IBA) $(0.5 \mathrm{mg} / \mathrm{l})$ for clonal propagation of Thymus vulgaris L. from stem nodal segments. Sáez et al. (1994) applied MS medium supplemented either with $6.6 \mu \mathrm{M}$ $\mathrm{BA}$ and $2.8 \mu \mathrm{M}$ indole 3 -acetic acid (IAA) or with $4.4 \mu \mathrm{M}$ $\mathrm{BA}$ and $1.0 \mu \mathrm{M}$ NAA to induce shoot regeneration from shoot explants of Thymus piperella L. In the course of the present study it was shown that $\mathrm{BA}$ at a concentration range of 0.5-5.0 $\mu \mathrm{M}$, preferably used in the mentioned studies, had no stimulatory effect on a multiple shoot regeneration from single node explants of $S$. baicalensis. Some combinations of BA with NAA (e.g. $2.5 \mu \mathrm{M}$ BA with $0.5 \mu \mathrm{M}$ NAA and 2.5 $\mu \mathrm{M}$ BA with 5.0 $\mu \mathrm{M}$ NAA) stimulated bud break and improved multiplication rate with reference to the control (Table 2 ). The shoot regeneration however, was accompanied by callus formation.

To achieve a higher multiplication rate from stem nodal explants of $S$. baicalensis, a two stage propagation system was elaborated using thidiazuron, which is one of the most potent synthetic cytokinins and is widely applied to induce in vitro organogenesis in woody plants (Huetteman and Preece 1993). In the first stage, nodal explants of $S$. baicalensis were inoculated on MS medium containing $0.5 \mu \mathrm{M}$ TDZ. After four weeks culture, a caulogenic callus emerged from each explant. The ratio of the final weight of the callus to the weight of explant reached $318 \pm 95$. The calli were transferred to the MS medium containing either $0.01 \mu \mathrm{M}$ BA and $26 \mu \mathrm{M}$ $\mathrm{GA}_{3}$ or $2.2 \mu \mathrm{M}$ BA (second stage). Multiplication rates achieved with those media, after the following four weeks, were $20 \pm 9.8$ and $25 \pm 6.8$ shoots per node, respectively. The excised shoots, at least $1 \mathrm{~cm}$ long, were further cultivated on modified MS medium (1/2 macronutrients) and $80 \%$ of shoots formed roots within two weeks. Although the two stage procedure of $S$. baicalensis micropropagation was shown to be efficient, a risk of somaclonal variation caused by indirect shoot regeneration should be taken into consideration.

\section{ACKNOWLEDGEMENTS}

This study was supported by the State Committee for Scientific Research (KBN) (grant No. 4 P05F 023 11).

\section{LITERATURE CITED}

GABRIELSKA J., OSZMIAŃSKI J., ŻYŁKA R., KOMOROWSKA M. 1997. Antioxidant activity of flavones from Scutellaria baicalensis in lecithin liposomes. Z. Naturforsch. C, 52: 817-823.

HUETTEMAN C.A., PREECE J.E. 1993. Thidiazuron: a potent cytokinin for woody plant tissue culture. Plant Cell Tiss. Organ Cult. 33: 105-119.

KIMURA Y., OKUDA H., OGITA Z. 1997. Effects of Flavonoids isolated from Scutellariae Radix on fibrynolytic system induced by trypsin in human umbilical vein endothelial cells. J. Nat. Prod. 60: 591-601.
KIMURA Y., OKUDA H., YOKOI K., MATSUSHITA N. 1997. Effects if baicalein isolated from roots of Scutellaria baicalensis Georgi on interleukin $1 \beta$ - and tumour necrosis factor $\alpha$-induced tissue-type plasminogen activator and plasminogen activator inhibitor-1 production in cultured human umbilical vein endothelial cells. Phytother. Res. 11: 363-367.

KIMURA Y., YOKOI K., MATSUSHITA N., OKUDA H. 1997. Effects of flavonoids isolated from Scutellariae Radix on the production of tissue-type plasminogen activator and plasminogen activator inhibitor-1 induced by thrombin and thrombin receptor agonist peptide in cultured human umbilical vein endothelial cells. J. Pharm. Pharmacol. 49: 816-822.

KONOSHIMA T., KOKUMAI M., KOZUKA M., IINUMA M., MIZUNO M., TANAKA T., TOKUDA H., NISHINO H., IWASHIMA A. 1992. Studies on inhibitors of skin tumour promotion. XI. Inhibitory effects of flavonoids from Scutellaria baicalensis on EpsteinBarr virus activation and their anti-tumour-promoting activities. Chem. Pharm. Bull. 40: 531-533.

LIAO J.F., WANG H.H., CHEN M.C., CHEN C.C., CHEN C.F. 1998. Benzodiazepine binding site-interactive flavones from Scutellaria baicalensis root. Planta Med. 64: 571-572.

MURASHIGE T., SKOOG F. 1962. A revised medium for rapid growth and bioassays with tobacco tissue cultures. Physiol. Plant. 15: 473-497.

NAGAI T., SUZUKI Y., TOMIMORI T., YAMADA H. 1995. Antiviral activity of plant flavonoid, 5,7,4'-trihydroxy-8-methoxyflavone, from the roots of Scutellaria baicalensis against influenza A (H3N2) and B viruses. Biol. Pharm. Bull. 18: 295-299.

NISHIKAWA K., ISHIMARU K. 1997. Flavonoids in root cultures of Scutellaria baicalensis. J. Plant Physiol. 151: 633-636.

OLSZOWSKA O., FURMANOWA M. 1992. Micropropagation of Thyme (Thymus vulgaris L.). In: Biotechnology in Agriculture and Forestry. Bajaj Y.P.S. (ed.). Springer-Verlag, Berlin Heidelberg, Vol. 19, High-Tech and Micropropagation III, pp. 230-243.

PATTNAIK S., CHAND P.K. 1996. In vitro propagation of the medicinal herbs Ocimum americanum L. syn. O.canum Sims. (hoary basil) and Ocimum sanctum L. (holy basil). Plant Cell Rep. 15: 846-850.

RYU S.H., AHN B.Z., PACK M.Y. 1985. The cytotoxic principle of Scutellariae Radix against L1210 cell. Planta Med. 51: 355.

SÁEZ F., SÁNCHEZ P., PIQUERAS A. 1994. Micropropagation of Thymus piperella. Plant Cell Tiss. Organ Cult. 39: 269-272.

SEO W.T., PARK Y.H., CHOE T.B. 1993. Identification and production of flavonoids in a cell suspension culture of Scutellaria baicalensis G. Plant Cell Rep. 12: 414-417.

SHETTY K., CARPENTER T.L., KWOK D., CURTIS O.F., POTTER T.L. 1996. Selection of high phenolics-containing clones of thyme (Thymus vulgaris L.) using Pseudomonas sp. J. Agric. Food Chem. 44: 3408-3411.

TAVARES A.C., PIMENTA M.C., GONALVES M.T. 1996. Micropropagation of Melissa officinalis L. through proliferation of axillary shoots. Plant Cell Rep. 15: 441-444.

YAMAMOTO H. 1991. Scutellaria baicalensis Georgi: In vitro culture and the production of flavonoids. In: Biotechnology in Agriculture and Forestry. Bajaj Y.P.S. (ed.). Springer-Verlag, Berlin Heidelberg, Vol. 15, Medicinal and Aromatic Plants III, pp. 398-418.

YANG R., SHETTY K. 1998. Stimulation of rosmarinic acid in shoot cultures of oregano (Origanum vulgare) clonal line in response to proline, proline analogue, and proline precursors. J. Agric. Food Chem. 46: 2888-2893.

YUN-CHOI H.S. 1992. Flavonoid components in plants of the genus Scutellaria. Kor. J. Pharmacogn. 23: 201-210.

YUN-CHOI H.S., YOO K.S., CHUNG S.H., YANG H.S., CHOI J.J., KIM Y.J. 1992. Flavonoids with bradykinin antagonistic effects from Scutellariae Radix. Kor. J. Pharmacogn. 23: 234-239. 


\section{MIKROROZMNAŻANIE SCUTELLARIA BAICALENSIS GEORGI}

\section{STRESZCZENIE}

Optymalizowano warunki dla rozmnażania in vitro roślin Scutellaria baicalensis Georgi (tarczyca bajkalska) (Lamiaceae) z fragmentów pędów zawierających węzeł i parę liści. Zastosowano pożywkę MurashigeSkoog'a (MS), do której dodawano NAA i kinetynę lub NAA i BA w różnych stężeniach. Najkorzystniejsza dla bezpośredniej regeneracji pędów z pączków pachwinowych była pożywka zawierająca $0,5 \mu \mathrm{M}$ NAA i 2,5 $\mu \mathrm{M}$ kinetyny, pozwalająca na uzyskanie 3,8 \pm 1,3 pędów z jednego eksplantatu, po sześciu tygodniach hodowli. W celu zwiększenia wydajności procesu mikrorozmnażania, opracowano również dwufazową procedurę regeneracji pędów z pączków pachwinowych. W pierwszej fazie, na pożywce zawierającej TDZ (0,1$-0,5 \mu \mathrm{M})$, uzyskiwano organogenny kalus z licznymi pạkami przybyszowymi. W drugiej fazie indukowano regenerację pędów, na pożywce zawierającej $2.2 \mu \mathrm{M}$ BA. Procedura ta pozwoliła na uzyskanie ponad 20 pędów z jednego eksplantatu. Zregenerowane pędy ukorzeniały się łatwo na pożywce MS ze zmniejszoną do połowy zawartością makroelementów i były z powodzeniem adaptowane do wzrostu w glebie.

SŁOWA KLUCZOWE: Scutellaria baicalensis, pąki pachwinowe, kalus kaulogenny, mikrorozmnażanie. 